\title{
Mozambique: The Rise of a Micro Dual State ${ }^{1}$
}

\author{
Maria Paula Meneses* \\ and \\ Boaventura de Sousa Santos**
}

\begin{abstract}
The decade from 1990 to 2000 was a period of sustained political activity in Africa, leading towards democratisation. Under this scope, Mozambique is widely seen as one paradigmatic success story. Yet, the country's multiparty democratic system remains challenged by a strong authoritarianism that hampers open deliberation in political public discourse.

This paper discusses some reasons for this democratic hold-up in Mozambique's political and social transition within the broad and ongoing democratisation process in Sub-Saharan Africa. With an emphasis on the analysis of the political situation in the northern town of Angoche, this article argues that the persistence of central government authoritarianism is a reminder of a political liberalisation without democratising the political systems. Indeed, local municipal officials are now elected and receive revenue transfers, but remain limited by other measures. ${ }^{2}$ The central state successfully resists attempts to devolve broader decision-making authority to municipalities.

Far from the ideal Weberian type of state bureaucracy, public administration is highly politicised in the sense that the building up of the administrative capacities of the state are seen as a way of consolidating the political leverage of the ruling party - Frelimo. The paper defends, however, that indeed, a detailed analysis of the public political actions at local level, between distinct political structures, shows that successive authoritarian regimes have not totally erased the freedom of speech and thought, even if they have relegated opposition to ever more marginal spaces.
\end{abstract}

* Maria Paula Meneses is a Researcher at the Center for Social Research of Coimbra University. E-mail: mpmeneses63@yahoo.com.

** Boaventura de Sousa Santos is the Director of the Center for Social Research of Coimbra University, he is also a Distinguished Legal Scholar at the University of Wisconsin-Madison, and a Global Legal Professor at the University of Warwick. Email: bsantos@ces.uc.pt / bsantos@wisc.edu. 


\section{Résumé}

La décennie 1990/2000 a été caractérisée en Afrique par une activité politique soutenue orientée vers la démocratisation. Dans ce cadre, le Mozambique est plutôt vu comme une réussite paradigmatique. Or, ce système démocratique de multipartisme continue à afficher des velléités d'un fort autoritarisme peu propice au relèvement du niveau de la réflexion dans le discours politique public.

Cette étude s'interesse aux raisons de ce blocage démocratique du processus de transition politique et social au Mozambique dans le cadre plus général du processus de démocratisation en cours en Afrique au sud du Sahara. En s'appuyant en particulier sur l'analyse de la situation politique de la ville d'Angoche, située au nord du pays, l'étude estime que le fait que le gouvernement central persiste dans l'autoritarisme est assez révélateur d'une libéralisation politique non suivie de la démocratisation des systèmes politiques. En effet, si les fonctionnaires municipaux locaux sont maintenant élus et reçoivent des fonds de transfert, ils restent, en revanche, limités par d'autres mesures. ${ }^{2}$ Le gouvernement central résiste avec succès à toute tentative d'élargir le mandat des municipalités en matière de prise de décision.

Loin du modèle idéal wébérien de bureaucratie d'Etat, l'administration publique est fortement politicisée, en ce sens que le renforcement des capacités administratives de l'Etat est perçue comme un moyen de renforcer l'influence politique du parti au pouvoir - Frelimo. L'étude défend le fait qu'une analyse exhaustive des actions politiques publiques au niveau local, entre des structures politiques bien distinctes, montre que les régimes autoritaires successifs n'ont pas totalement supprimé la liberté d'expression et de pensée même s'ils ont repoussé l'opposition encore plus loin dans les espaces marginaux.

\section{Introduction}

Our previous research on the specifics of the Mozambique state led us to define it as being composed of a very heterogeneous set of institutions in which different political and legal cultures, practices and institutions coexist with little overall coherence (Santos, Trindade and Meneses 2006). ${ }^{3}$ This heterogeneity can be traced to the colonial past (until 1975), the peripheral position of the country in the modern world system and the vulnerability it creates to foreign impositions, the regional cultural and religious influences, some of them dating back to the pre-colonial period, and the political and ideological changes that came with the independence. This diversity of political and legal cultures operates in conditions in which the state (and the central Government) lacks the capacity or the political will to arbitrate their relative influence. It translates itself in a complex form of legal pluralism 
filled with spontaneous development and kept alive by social demand and creativity. The coexistence of different institutions and different philosophies with similar competences does not necessarily lead to conflicts among them; rather, their differences may be an asset to be capitalised by the Mozambicans.

As a result of our research, we have reached several conclusions:

- The first conclusion is that the Mozambican state is a heterogeneous state whose political form consists of lawyers of different political cultures: colonial state, socialist, liberal capitalist, African traditional and Islamic cultures which coexist in complex ways, giving rise to the hybrid forms of political rule and practices. The binaries usually invoked to characterise politics in Africa as modern/traditional, western/non-western, democratic/authoritarian, official/non-official are too narrow to embrace the complex and hybrid forms in place which are differently located in a continuum between the polar binary positions.

- The second conclusion is that very far from the Weberian ideal type of state bureaucracy, public administration is highly politicised in the sense that the building up of the administrative capacities of the state are seen as a way of consolidating the political leverage of the ruling party, Frelimo. ${ }^{4}$ This top-down conception is consistent with a bottom-up view, the view of the people for whom the administration structures are Frelimo structures.

Taken together, these two conclusions show that democratic institutions be they the multi-party system, the formal independence of the judiciary, or the process of decentralisation - coexist with a single party political structure both as a practice and as a social representation shared by public officials and the population alike.

- Our third conclusion is that, at the base, in a broad contact zone between the state and society/community, a vast range of dispute resolution mechanisms operate such as: community courts, traditional authorities, healers, ${ }^{5}$ neighbourhood secretaries, religious leaders, local administrative leaders, as well as other components of the civil society, mainly represented by non-governmental organisations (NGOs). They operate as loose network. They co-exist either in parallel or in complex interactions, such as when a given conflict is divided up in different issues or sub-conflicts, some of them to be dealt with by one of the institutions and others by others, or when one institution functions as an instance of appeal for dispute non-satisfactorily settled by another institution, or still when one institution is called upon to help (evaluating or providing evidence, for instance) in the decision of case submitted to another institution. 
Between 2003 and 2008, and for the first time in Mozambique, an opposition party - Renamo - took the control of five municipalities in Mozambique, one of which was Angoche, a small city in coastal northern Mozambique (Nampula Province).

The case study of Angoche provides the basis for this study. Angoche represents a challenge to the exercise of central authority and to local democratisation. The mode of operating of the heterogeneous state is transformed when another rival political force takes over the power to rule the municipality.

As we will seek to demonstrate in this paper, the complex landscape of political and judicial structures and practices changes dramatically when the level of political contestation rises above a stabilised level or when global external factors combine with internal factors to change the pattern of dispute resolution. When this occurs, the network is segmented and the choices for floor shopping may decrease even when the numbers of dispute resolution institutions increases. Moreover, the parallel or cooperative coexistence among different dispute resolution institutions is replaced by a competitive coexistence which in the end aims at eliminating coexistence altogether and at replacing it by rival single sets of institutions each one affiliated with a specific party.

One of the significant impacts upon the heterogeneous state is its transformation - to a certain extent - into a dual state, a Renamo state and a Frelimo state, co-existing side by side. As a result, the politicisation of public administration, which is typical of the heterogeneous state, escalates to a new level, a hyper-politicised level.

The first part of the article links an analysis of the current process of reform at the local level with a re-examination of the history of the power struggles in northern Mozambique, stressing the specificity of the urban settings. The overview of the colonial system provides the necessary contextualisation for an analysis of the transition to independence, when the city was 'taken over' by Frelimo and the urban management system was transformed in order to 'fit' the image of the 'new society' to be built as 'free from the remnants of the past traditions' (Machel 1985:105-106). This section of the text also includes an analysis of the political impact of Islam in northern Mozambique, with a strong emphasis on Angoche modern history.

The second section of this paper seeks to broaden the theoretical discussion on the very nature of the Mozambican state. The 'new' policies of decentralisation in Mozambique are privileged stages to analyse the power struggles over their control by different political forces - mainly Frelimo and Renamo. Our data suggest that the process of political decentralisation in Mozambique has been largely controlled by the central government, with a 
strong hold over political and financial processes. In the few municipalities where Renamo won the elections, Renamo behaved, again, as a mirror-image of Frelimo; that is, as a single party local system, therefore blocking the way to a truly democratising process of the Mozambican society.

In sum Angoche was chosen for two main reasons: the strong political presence of Renamo, the main opposition party to Frelimo, and the equal strong presence of Islam in its multiple versions.

Much of the literature on local affairs in Africa tends to be centred on political struggles, disputing power in large urban centers. Therefore, the most remote and less urbanised municipalities are seen as symbols of backwardness in areas where other 'unspoiled' authentic forms of the 'tradition' have been in practice for centuries. The assumption is that the efficacy of the 'tradition' rests upon the moral legitimacy of the codes shared by the ethnic group; the same researchers tend also to assume that people resort to these forms of administration in the absence of modern Western systems of governance (Grest 1995; West and Kloeck-Jenson 1998).

The field data discussed in this paper refer mainly to the period between 1995 and 2006. Field research has been supplemented by official government documents and publications, press reports and related studies on this area, including documents and studies on economic and human development in the country. The major sources of information, however, are interviews and direct observations of multiple instances and actors involved in the decentralisation process both at the central level and in Angoche - Nampula province, such as staff of the Ministry of state Administration, administration officials and staff, the mayor and municipal staff, community judges, community political and religious leaders, etc. Interviews were semi-structured and interactive.

\section{The Historical Context}

\section{Colonialism and Space Ordering in Urban Mozambique}

The modern Portuguese colonial administration had been present in Mozambique since the end of the nineteenth century. Colonialism introduced a 'modern' system of urban government - villages and cities had the status of municipalities, with a specific system of local government. This system of local government - highly centralised and independent of the metropole was very discriminatory as it was mostly found in urban areas where the Portuguese settlers lived. The 'African administration' existed at the level of district and had far fewer resources at its disposal to provide services for the bulk of the African population living in suburban areas (caniço neighbourhoods) in very precarious conditions. ${ }^{6}$ 
As several colonial officials have described (Rita-Ferreira 1967-1968; Mello Machado 1970), the African neighbourhoods were ruled by local régulos. ${ }^{7}$ These traditional authorities (and the norms they would apply) were a colonial construction, produced along the contact zone between colonial administration and 'local' African authorities (Santos and Meneses 2006). In urban contexts the procedures, rules, and fines they administer were established through a negotiation between the Portuguese colonial authorities and these new 'native' authorities, in order to overcome the potential anarchy. Régulos consider their own authority to collect taxes, to govern the territory under their control, which included settling disputes, sometimes even backed by the civil, police and military authorities (Meneses et al. 2003). They did not articulate a sense of 'customary' as something distinctive, autochthonous, locally derived, or essential to local identity.

In the early 1960s, the beginning of the nationalist armed struggle in Mozambique forced a revision of several aspects of the Portuguese colonial policy. Among the various political measures, the Estatuto do Indigenato was revoked, ${ }^{8}$ theoretically giving Africans the full rights of Portuguese citizenship (Meneses 2007:13-15). The colonies were also re-labelled 'overseas provinces' and formally given more autonomy. This make-up of political decentralisation in the last phase of colonial rule sought to accord greater authority to organs of colonial administration. However, the centralised nature of decision making at local level remained a dominant feature of the system. Similarly, the segregationist policy of 'cement city' for the colons and the neighbourhoods for the Africans changed more in appearance than in practice. Indeed, the Câmara Municipal remained the administrative institution of the 'cement city', while de facto African neighbourhoods were ruled by régulos and the district Administration. The strict enforcement of municipal building standard by-laws ensured that there were very few African property owners in the cement part of the city with a property register. ${ }^{9}$ It should also be mentioned that supporting services (current water, sewage, etc.) that required specific technical competence of the urban services, were virtually nonexistent outside the cement part of the cities, although efforts to upgrade this situation were undertaken in the late colonial period, as part of a tardy and ineffective strategy on the part of the colonial administration to defy the call for self-determination and independence. But probably the most striking characteristic of these urban settings was a total absence of any firmly rooted tradition of democratic citizen participation in local urban government. 


\section{Independent Mozambique}

In 1975, Frelimo, the leading nationalist movement took over the power from Portugal. Frelimo was very conscious of the reality it inherited, characterised by poverty, inequality, and no political experience other than colonial authoritarian rule. Seeking to break away from it, Frelimo aimed at imposing a 'new' alternative administration system, imported from the liberated zones. All activities considered to cause internal divisions based on cultural factors - such as religion, ethnic, urban identity - were considered a threat to Frelimo's unity policy to 'build the nation'. ${ }^{10}$

The conflation of economic and political self-determination resulted in a systematic underestimation of the importance of local political institutions, both in rural and urban contexts (O’Laughlin 2000; Francisco 2003). Worse, the cities and towns were viewed as the privileged locus of colonial capitalism (Machel 1985). Frelimo's misreading of its African social basis prevented it from imagining how indigenous experiences might act as bases for social transformation within an evolving national political-economic context. It also generated authoritarianism and operational incompetence, both in planning and in carrying out state policies.

As a result, the political and administrative system became heavily centralised: everything was planned and decided at the centre of political power, in Maputo. ${ }^{11}$ But because the party-state ought to organise the participation of all the citizens to overcome the country problems, a strong emphasis was placed on the restructuring of 'alternative' forms of people's administration. At local level (neighbourhoods and working places), Grupos Dinamizadores - a new structure - became the link between the Frelimo and the state. Simultaneously, inherited forms of local government power were abolished: the municipalities, ${ }^{12}$ as well as the traditional and religious authorities (mostly in rural contexts), ${ }^{13}$ as part of a project to radically reform local government.

In 1977, after transforming itself into a vanguard party (Brito 1988), Frelimo introduced a more formal hierarchy of party cells and circles, each headed by a secretary. As a truly single party-state, the broad mass of the population was to be incorporated into the political process through mass democratic organisations under the control and tutelage of the party.

Frelimo's endeavours to build new local institutions were authoritarian from the very beginning; without minimising the importance of outside forces in shaping the civil war that ravaged the country for more than a decade, the growing alienation of Mozambicans towards Frelimo's ineffective policies and loss of legitimacy inflamed the civil war in the country. ${ }^{14}$ The rapid deterioration of the economy, the destruction of infrastructures and of the 
public administration by the war, the lack of economic, administrative and technical capacity, increasing poverty and extensive migration and displacement of the population made an economic rehabilitation programme a central issue by mid-1980s.

\section{The National and the Local in the Process of Democratisation}

The quest for democratisation emerged in Mozambique as a process of improving the state competence, making it more accountable and responsive to local needs, while granting more autonomy to local organs. This position coincides with a shift towards a more liberalised polity and economy in the country. After Mozambique joined the Bretton Wood institutions, by mid1980s, the quest for downsizing the presence of the state, as part of the process of political decentralisation, became a crucial political element, similar to other situations in the continent (Abrahamsson and Nilsson 1997; Manor 1999; Santos 2006). Simultaneously, a new constitution (1990) established the freedoms of religion and political expression, emphasising civic participation in local development and in deepening democracy. ${ }^{15}$

In the context of the modern nation-state, multiparty elections are often the epitome of democracy. Accordingly, great emphasis was placed upon the successful staging of the first national elections in Mozambique. In the words of Weimer:

Peace in Mozambique first and foremost means that the political conflict fought out between Frelimo and Renamo in a bloody war has been civilised in the sense that both its theatre and instruments have changed: from the bush to the parliament and from weapons to words, respectively (1996:43-44).

Above all, the elections were perceived as a means of ending the civil war and of rationalising political contestation, by making contestants (and their political projects) directly accountable to Mozambicans.

In 1997, the first municipal elections took place in 33 cities and towns; ${ }^{16}$ a few years later, the government built up a legal structure to incorporate 'community authorities' (that is, civil leaders, including traditional authorities'), into the process of local governance. All of these measures were endorsed by Western donor states and several international organisations, for which Mozambique is portrayed as a 'success story' of implementation of national policies towards the enhancement of peace, stability and economic growth (Lundin 2000; Carbone 2005; OECD 2005; World Bank 2005).

\section{Angoche, Northern Mozambique}

The population of Angoche is of about ninety thousand people, with an overwhelming majority of Muslims. ${ }^{17}$ Angoche belongs to the large area of northern Mozambique with a predominantly makhwa population, a society that 
maintains, albeit in a constantly changing form, a culture in which chiefs, land and ancestors are still important (Newitt 1972a). Furthermore, since the height of the slave trade, Islam has become the main religion of the coastal areas, co-existing with older beliefs about land and ancestry (Bonate 2007). Angocheans have agricultural fields outside the city and are also involved in fishing to a great extent. ${ }^{18}$ Trade, crafts and industry are in decay, as a result of the civil war and IMF and World Bank economic policies, these latter directed at the production of cashew nuts. Only after 2004 was the cashew production re-taken in the district. ${ }^{19}$

Until the beginning of the twentieth century, the north of the former Portuguese colony of Mozambique was in fact ruled by a group of Muslim (Swahili) shaykhs and sultans whose power derived from slave trade which flourished in this region from mid-nineteenth century (Newitt 1972b; Capela 2002). Throughout the nineteenth century, these sultanates and sheikdoms acted in relative autonomy. ${ }^{20}$ The fictitious rule by the Portuguese was based in a politics of survival that consisted in incorporating the Swahili rulers in the colonial administration, the administração de terras firmes. ${ }^{21}$ Receiving a salary and an army commission, the sultan and shaykh were theoretically part of the Portuguese administration, serving on behalf of the Portuguese crown. In fact, this was a fiction, a game that both parts played in view of the mutual advantages they got from their collaboration. For instance, while the Portuguese paid the sultans a salary, they regarded it as a tribute for Portuguese sufferance (Hafkin 1973:xii; Santos e Meneses 2006). They performed duties as vassals only when it furthered their self interest. As a result, until the end of the nineteenth century, the Portuguese inhabitants of northern coastal Mozambique (the moradores) ${ }^{22}$ were deeply entangled in local politics dominated by Africans (Pélissier 2000, vol. 1: 133, 159-164). All this started to change at the end of the nineteenth century with the Berlin Conference and the need for the Portuguese to substitute historical claims for effective occupation as a basis for their colonial rule. This fact, together with the fall of slave trade, brought to an end the prominence of the Swahili city-states in Mozambique. The Portuguese finally took control of Angoche in 1910 (Bonate 2003:118).

\section{Islam, the Customary and Colonialism}

Angoche, as all northern coastal area of Mozambique, has a strong Muslim presence, embedded in the core of local chieftainships (Bonate 2006). Around the city, bordering with the district, there are scattered settlements, whose key figure is the mwénè. The title of mwénè is attributed to the chief, a person with recognised wisdom and support beyond his traditional area of influence. ${ }^{23}$ 
In the past, the city was ruled by the Anhyapako. ${ }^{24}$ Today, they remain influential in the region (especially in Inguri, a neighbourhood of Angoche), and the word 'anhyapako' is still used to define the 'old rulers'. As said above, by the mid-nineteenth century, Angoche Sultanate turned into an important destination for slave traders from the interior of the continent, and the Anhyapakho were able to build up a web of alliances through conquest and kinship relations all over the region that allowed them to raid and access mainlanders for enslavement (Hafkin 1973:145-147, 344). The military actions undertaken by the Shirazi ruling elite of Angoche contributed to the greater expansion of Islam, by the build-up of a web of allies through kinship relations. This new identity was primarily extended to the ruling elite - the web of paramount chiefs of the mainland - whose power and authority, like that of the Swahili, rested above all on the premise that they were lords of the lands and on their identity as Muslim rulers. As a result, Islam became no longer associated only with coastal Shirazi Swahilis, but became an inclusive a broader faith of all Muslims, now identified as the Maca. ${ }^{25}$

However, in Mozambique, as elsewhere, the diversity of the manifestations of identification with Islam is very visible since the nineteenth century. This period coincides with a combination of sociopolitical factors which made possible the rise of new groups competing among themselves 'over interpretation of the symbols and the control of the institutions' (Eickelman and Piscatori 2004:5). Around that time several Sufi orders made headway in coastal northern Mozambique. Their arrival coincided with an increasing presence of colonial administration, with the Muslim chiefs leading the resistance against the Portuguese (Pinto de Carvalho 1988; Bonate 2007a:135-142).

As illustrated by Bonate (2006:143-144), the integration of African chiefs into the colonial system of Indigenato and the modernisation processes which took place between the 1930s and 1970s did not halt the expansion of Islam in northern Mozambique. However, the colonial intervention, by fixing the dynamics of local power struggles, maintained the legitimacy of 'African chiefs' - now as 'traditional authorities' - throughout the twentieth century, using them to control local populations (West and Kloeck-Jenson 1998:473476; Meneses 2007:16-18).

With the emergence of the struggle for national liberation in the early 1960s, most of the Muslim leaders of northern Mozambique supported the nationalist struggle. This was due not only to the impact of the anti-Muslim policies of Portugal, but also due to the strong influence of the wide Muslim network in East Africa, supporting the independences (Bonate 2007b). In response, the Portuguese brutally repressed the chiefs supporting Frelimo. The colonial administration was concerned with the nationalist movements and identified Muslim xehes ${ }^{26}$ and Sufi Orders as representing a religious 
leadership for the majority of northern Mozambique (Amaro Monteiro 1993:303-311; Bonate 2007b:56). Not only did the Portuguese administration give public support to Sufi rather than to the Wahhabi group that began emerging in the 1960s; they also reconsidered several aspects of their colonial policy.

In the second half of the 1960s, the situation in Angoche in fact improved, with, for example, the (re)construction, of the 'new Inguri', an African neighbourhood geometrically organised and with high-quality buildings. ${ }^{27}$ This process went together with an increasing support to loyal régulos, especially in northern Mozambique, where the pressure of the war of liberation was on the rise. Colonial administration even built houses and administrative offices for the régulos in the two major African neighbourhoods of Angoche - Inguri and Puli. ${ }^{28}$ As reported by one of the régulos, 'back then we were very much loved by the Administrator'.

\section{Frelimo: Transformations and Continuities}

With independence, Angoche, which had been for some decades an important centre of cashewnut production and processing, was ruled by Frelimo, as any other city in the country. Also, Frelimo set out new structures of state and party. Since the Câmaras had been abolished in 1978, the municipal coun$\mathrm{cil}^{29}$ was given the task to reorganise the administrative structure of the city.

Frelimo leadership envisaged a united and modern nation-state where there was no place for social and cultural difference. Since 'Frelimo came and removed us [régulos] from our houses and took away our authority’, 30 new administrative, executive and judiciary structures were introduced. In Angoche, as elsewhere, the large African neighbourhoods were reorganised, and transformed into communal neighbourhoods, now directed by the local secretary of the Grupo Dinamizador. The neighbourhoods were divided into smaller units - quarteirões - headed by a chief. ${ }^{31}$ This new structure sought to transform the life of the 'new' Mozambican citizen. For example, and as we will discuss further, the girl's rituals of initiation, considered by Frelimo a symbol of obscurantism - were transformed into a new tradition - 'the paramparas', to be carried out under the auspices of Frelimo. For that, a person had to apply to the neighbourhood secretary for permission, which included the payment of a fee.

Besides being removed from the cultural sphere, religious groups faced official condemnation, as religion was identified as an element of obscurantist colonial culture. With this, the traditional authorities in Angoche lost another support of their power, that of Islam.

The multiple cultural encounters have produced a complex palimpsest of normative processes, generating a modern legal landscape crossed over by 
multiple juridical traditions, including African indigenous and Islamic legal cultures. As a result, the majority of the population of Angoche was never under the monopoly of state law. With independence, the traditional and religious authorities (régulos, xehes, etc.), which up until then had performed an important role as a dispute resolution institutions, (besides the usual colonial assignment: control of population, land and labour management) were prohibited. As a solution, Frelimo sought to institute a popular court in Johar, a neighbourhood of Angoche. With civil war, the popular court was transferred to Parapato, at the very city centre. With the changes brought about by the 1990 Constitution, it was renamed a community court, but continued to operate in very much the same way and with the same lay judges. ${ }^{32}$

Although these judges were supposed to be formally elected, Frelimo's trust was the fundamental requisite: 'I was chosen and not elected to the court, because I was a person Frelimo trusted' '. ${ }^{33}$ A presiding judge of the main community court of Angoche confided: 'I was chosen [to be a judge] at my neighbourhood because I was a party delegate. It was the party [Frelimo] that chose me for this place' ${ }^{34}$ Indeed, several negative criteria barred a large proportion of the people from Angoche from being active, participating citizens: traditional chiefs and their subordinates, religious leaders, polygamists, etc., were to be excluded. As a result, these official positions became part and parcel of local struggles over state patronage, access to goods and to authority between youth and elders and among lineage leaders (Geffray 1991; Alexander 1997).

Angoche was never taken by Renamo during the civil war, but endured a severe siege. The tremendous economic and military pressures the city faced led to an increase divide among the population, with Renamo controlling very much of the district, including the suburban areas of Angoche. At the end of the war Renamo was perceived as the responsible for some of reversals of Frelimo's policies, such as those toward the church and the traditional authorities. As a result, with the end of the war and the economic crisis that followed, ${ }^{35}$ Angocheans increasingly felt 'abandoned by the state [central government], there was nothing to live here with', ${ }^{36}$ resulting in a significant increase in the number of Renamo adepts. In parallel, the cases of corruption by state officials and staff were evident and ever-present. By mid-2003, several cases were still fresh in people's memory, concerning corruption involving community court judges and secretaries. ${ }^{37}$ Seeking to explain the corruption in the city, people would refer to the harsh economic situation, exclaiming 'bribery is food in our city'! ${ }^{38}$

\section{Democratic Decentralisation and the Rise of Dual State in Angoche}

During the negotiations that led to the General Peace Agreement of 1992, power sharing and pluralism was envisaged even at the local level (Braathen 
and Jørgensen 1998:31), although this was not contemplated in the Peace Agreement. In fact, in parallel with the multiparty-national elections, other political reforms were shaping a broader process of democratisation. Just prior to the first multi-party national elections (1994), the still single-party Parliament approved the Municipalities Law, ${ }^{39}$ providing for the (re)introduction of municipalities with greater executive power (to be elected on a local basis). A couple of years later, in 1997, two new laws were passed, creating the legal and institutional framework for the municipalities. ${ }^{40}$ These laws created the basis for devolution to democratically-elected local governments in thirtythree large cities and towns in the country (Hanlon 1997; Alves and Cossa 1998). As a result, most of the rural population was excluded from local democracy, as Frelimo's government continued to appoint local officials, from district administrators down to neighbourhood secretaries and community police. In 2003, during one of the interviews, the very own secretary of Angoche-sede neighbourhood justified his position by saying 'I was chosen by the population, under the Frelimo's orientation', a statement quite similar to the one made by the secretary of Cerema neighbourhood.

Another problematic area was related to the role to be given, in this new context, to traditional authorities, since this political figure remained omnipresent (Alexandre 1997; Lundin 1998; West and Kloeck-Jenson 1998; Meneses et al. 2003). If Renamo (and other opposition parties) demanded the immediate and unconditional recognition of customary institutions as authentic representatives of Mozambican cultural identity, Frelimo was more cautious in meeting formally with customary authorities and negotiating their integration in the governance system. By recognising the hereditary privileges and pluralist notions of law the customary authority symbolised both a return to the past in terms of an unscientific world of the 'tradition' and negation of modern unitary (West and Kloeck-Jenson 1998; Meneses 2007). Realising their social importance, Frelimo opted to reinstate traditional authorities. ${ }^{41}$ From 1991 to 1997, the government commissioned a broad research on this subject. ${ }^{42}$ The goal of the research was to identify 'truly' traditional authorities that had not been tainted by colonial and current party politics (Lundin 1998); in parallel, the government sought to acquire sound information upon which to develop a legal framework for articulating both the activities of traditional authorities within the broader state structure. As depoliticised spheres of personal trust and community-based networks, traditional authorities emerged in this project as homogeneous groups, representing 'the whole community, beyond political differences, embodying the will of all the people, and not excluding anybody' (Cuahela 1996:11). After a turbulent period of discussion, in 2000, the Mozambican government passed a Decree that recognised the 
diversity of authorities present at local levels. Although the Mozambican state has claimed a radical cut from the colonial past, this Decree clearly assumed a depoliticised and timeless idea of the African community and traditional authority, described now as 'community authorities'. ${ }^{43}$

The picture that slowly emerged was that municipal elections - as the expression of local democracy - would take place in the thirty-three municipalities, while the other forms of 'authority' were to be legitimised and recognised by the state in rural settings.

The first municipal elections were scheduled to take place in 1998. Because people in Angoche, as elsewhere in the country, had experienced authority derived from the state (in whose voice local officials spoke), the anxieties and confusions were significant. The role of traditional authorities remained outside the political ballot, as several other questions Renamo had fought for. For example, at the time, one of the strategies of Renamo was to lobby against the payment of urban taxes, arguing that taxes should be abolished because people were poor. This was done in order to boycott the local elections; at the same time, Renamo and many other smaller opposition parties toured the country with an anti-election campaign, trying to convince the people to avoid the electoral act. ${ }^{44}$ Local people feared that the instability created with the elections campaign could lead to violence, sparking fears of the repoliticisation of the state. The attitude towards the elections was of total demobilisation. As a result, the elections were won by Frelimo's candidate, who obtained 75 per cent of the votes, with a turnout of only of 35 per cent.

What remains important, but is frequently less discussed, are the attitudes towards reform held by those whom decentralisation affects. Here, we focus on the implications of the election of Renamo's mayor in Angoche, and the role and attitudes displayed by other local political actors.

\section{Implications of Decentralisation - Renamo's Victory in 2003}

The second municipal elections provided Angocheans the opportunity to choose those who would govern them at the most proximate level. Many Angocheans were displeased with the Frelimo appointees who had long governed them. Several scholars writing about the power logics in the continent have called the attention to the importance of redistribution of wealth (Bledsoe 1980; Vansina 1990; Feliciano 1998). Likewise, power in Angoche has been measured in terms of one's capacity to attract and sustain subordinates. Rulers that abuse subordinates or who failed to create a mutually beneficial environment, in which they might live, face the possibility of not being voted for. The Frelimo mayor deceived the Angocheans, particularly after the enormous economic crisis the city went through. 'Unemployement is the worst ever. Our children finished high school and can't find a job...' 
sadly remarked a Shaykh in Angoche; ${ }^{45}$ and the comments about the personal misconduct of the mayor, in terms of personal favours and corruption, were widely discussed in the city. ${ }^{46}$

The victory of Renamo in Angoche in the 2003 municipal elections brought into light a new dimension to the over-politicised nature of public administration with a decisive impact on the rich legal pluralism identified in our previous work.

After the municipal elections of 1998, Angoche was divided into five administrative units (Unidades Autárquicas): Parapato, Inguri, Johar, Cerema and Mussoriri. ${ }^{47}$ In the early 2000, the municipality, controlled by Frelimo, decided to create Justice Commissions in the different administrative units. Later on, these commissions - organised and driven by the District and Municipal administration - were transformed into community courts, supervised by the Ministry of Justice. ${ }^{48}$ Therefore, since 2002, there were five community courts in operation.

As it happened in the rest of the country, the base or grassroots level public administration was formed by the Grupos Dinamizadores, a Frelimo political structure.

With the political changes introduced by the 1990 Constitution, namely the introduction of multipartidarism, the Grupos Dinamizadores formally disappeared but indeed continued to exist under the name of the neighbourhood secretaries, exercising basically the same functions as those of the Grupos Dinamizadores. As Orlando Abuque explained, 'the changes occurred with Decree 15/2000, and in the place of the secretary of Grupo Dinamizador, now we have a neighbourhood secretary'. ${ }^{49}$

Angoche was hard hit by the civil war and after the peace agreement the tensions between Frelimo and Renamo were still very much present. Probably more than in other regions of the country, the community courts were identified with the Frelimo while the traditional authorities were identified with the Renamo. ${ }^{50}$ The suspicions derived from the fact that the community courts had been recently created with support of a municipality run by Frelimo. But the roots of the problem laid in the memory of the Angocheans; the judges had been selected in open assemblies in the neighbourhoods, under proposal of old popular court judges and the Municipality. ${ }^{51}$ Renamo played on this process. During the electoral campaign, Renamo supporters would comment 'those people from community courts do not know what justice is, they are all selected by the Grupos Dinamizadores. For us justice is done within the community, with the support of the régulos' ${ }^{52}$ In spite of the tensions thus created, these base level institutions operated in conjunction, building a network that gave the people some choice in the selection of the best suited mechanism to settle a given conflict. 
When, in 2003, the Renamo won the municipal elections, all this started to change dramatically. Right after the elections, the old representatives of the administrative units ${ }^{53}$ were removed, replaced by new ones chosen by the new mayor (president of the Municipal Council). But the structure hierarchically below the director of these units were the secretaries, most of which 'has been formed by the Party [Frelimo] and that are working with the municipality, as part of the government. We always worked with them'. ${ }^{54}$

The first conflict emerged in the relations between central government, represented by the district administration and the municipal government. A good illustration was the withdrawal, from the neighbourhoods, of the INASS - the National Institute of Social Services - that distributes pensions and other social benefits.

Frelimo's enforced neighbourhood administrative structure was not supported by the state, or by the municipality. As a means to partially resolve this situation, the INASS agreed to financially support several people - most of them neighbourhood secretaries - in return for acting as mobilising agents for their social activities. ${ }^{55}$ As expressed by several of the secretaries interviewed, they would 'work for free as permanentes', ${ }^{56}$ although they were perceived as 'working for the state'. From this agreement, made with the previous municipal government, the representative of INASS could use the premises of the administrative unit in the different neighbourhood to deliver the cash payments.

With the change of the political colours in the municipality, the INASS dependent on the central government - remained an important asset for Frelimo's functioning in the neighbourhoods, becoming a channel for political influence. ${ }^{57}$ INASS permanents would primordially provide for those elders who would vote for Frelimo: 'INASS belongs to Frelimo; they charge for those cards to get the alimony, so that they would vote for Frelimo. They are deceiving the elders' ${ }^{58}$ But the new mayor demanded broader power over the permanentes collaborating with the INASS, seeking to replace them with his own (Renamo) people. ${ }^{59}$ In parallel, the director of the administrative unit of Inguri complained vehemently in a letter, expressing in writing protests against the political use of pension payment for electoral purposes. ${ }^{60}$ Because INASS did 'not want to be controlled by us', ${ }^{61}$ the Institute stopped the campaigns in the neighbourhoods, maintaining open only the headquarters, located in the town-centre.

The municipal government denounced this withdrawal most vehemently emphasising the damage caused to innocent citizens, some of them quite aged, now forced to walk a long distance to the INASS headquarters. Given the pattern of promiscuity between politics and public administration, both parties 
in the conflict shared the idea that the disbursement of the cash payments in the administrative unit, now staffed by Renamo people, would be seen by the people as a given away of the Renamo state rather than of the Frelimo state.

\section{Conflict and Segmentation Between Base-level Modern Structures of the Local State}

Soon after the nomination of new leaders for the five administrative units, conflicts between them and the community courts ignited. We analyse here two cases: the community courts of Cerema and of Inguri. A common characteristic for both cases is the fact that the administrative unit and the community court share the same premises. It should be mentioned that some of the previous directors acknowledge their interference in the matter of the courts. As described by one of the interviewees, an administrative official previously under Frelimo's local administration:

Because the court was working in the same house as the administrative unit, every time I knew that there was a problem I was informed of it; when the judges felt hopeless in solving a case, sometimes they invited me, and I participated in the search for a solution. ${ }^{62}$

The conflict started over the request of the Directors of the administrative unit to be present at the court sessions, and to receive a copy of the monthly report, the community courts are supposed to send to the Notary and Register offices of the Ministry of Justice.

One of the Judges explained how it happened in the Community Courts:

Our problem was that they wanted to see the report and we said 'that is not your competence', since we have not yet been instructed to deliver the report to the Municipality. We are only accountable to the Register and Notary office. And we refused to hand the director [of the administrative unit] a copy. ${ }^{63}$

In Inguri, initially, the judges, following the request of the new Director, prepared a daily summary of the cases. Shortly after, and following the other courts decisions, that 'municipality is the municipality and the courts are courts' ${ }^{64}$ this process was discontinued. The director then offered to attend the court session, 'in cases the judges thought it could be important for the municipality to know exactly what was happening ${ }^{9}{ }^{65}$ But the possibility of cooperation between the municipality and the court was refused by the presiding Judge, arguing that this procedure was not a practice in the community courts. ${ }^{66}$

In both cases, through their president, the community courts denied the requests invoking the independence of the administration of justice. Their justification was problematic as, according to the law, the community courts, 
contrary to the official court system, are independent of the Ministry of Justice. However, for the Director of Unidade Autárquica of Inguri, the refusal to access to the reports was perceived as a symbol of non recognition of the legitimacy of Renamo's city authority in the Municipality. ${ }^{67}$ However, the real argument was, as 'everybody knew', that the community courts were a structure of the Frelimo and since the municipal government belonged now to Renamo, the latter assumed to have the right to control the community court and substitute the judges. In the different courts visited, the judges would describe how the courts had been visited by a brigade from the municipality, with the aim of promoting new elections for the community courts, to replace the current judges. Later on, in some neighbourhoods, things began to settle down. On the several occasions that we attended the courts, people who we interviewed would explain that they were seeking the court's assistance because 'the court was no longer working for the political parties'.

In Cerema, the administrative unit and the community court, in spite of the tension, found a peaceful modus vivendi. As expressed by a Judge of the Community Court, 'now we understand each other. The cases can be brought up to the administrative unit, but they forward it to us' ${ }^{68}$ However, in Inguri, the conflict became very intense and it included mutual insults and physical aggressions. The intensity of the conflict had a decisive impact on the performance of the community court. While Cerema continued to hear cases, the Inguri community court, once a very lively one, was deserted by the people and very few disputes were brought to it for settlement.

This was the first dimension of conflict between Renamo and Frelimo concerning the modern institutions of the state (the administrative unit and the community court). But soon after, a second dimension emerged, involving other modern institutions. Unable to control the community court or to replace the neighbourhood secretaries, the municipal government decided to create its own neighbourhood delegates, with the same functions as the secretaries, and to fill these positions with Renamo members. As referred by the Administrator of Angoche district, in 2004:

Now, in the neighbourhoods, the secretaries of the Grupos Dinamizadores are no longer trusted by these newcomers of the Municipality. They [Renamo] have placed their own people to control the neighbourhoods. These new people no longer obey us. ${ }^{69}$

With this, the base level administration was segmented or divided according to party lines and a micro parallel or dual state emerged: a Renamo state side by side with a Frelimo state. This competitive duality led to conflicts that left the people confused and powerless. 
The newly elected officials, under strong pressure to raise funds, were seeking to take control over local taxes, and at the same time to fulfil their previous electoral promise. During the 2003 electoral campaign, Renamo adepts would mobilise people in Inguri claiming 'if you chose Renamo, you won't have to pay taxes' ${ }^{70}$ The struggle to control the authorisation to celebrate the parampara ${ }^{71}$ - the initiation rites - became a frequent type of conflict in Angoche. Formalised long before by Frelimo, it was a prerogative of the neighbourhood structure to grant this authorisation: 'Before we used to apply for permission to OMM. ${ }^{72}$ Now, the ones from Renamo ask Renamo, the ones from Frelimo continue to seek permission from the secretaries, but it is not working... ${ }^{73}$

Besides, the fees obtained were used by the Grupos Dinamizadores members as sources of income. Trying to fulfil the political promise, Renamo would issue the need authorisation for free, demanding in return that people would apply for it at the administrative unit. As a result, multiple conflicts of power emerged. We witnessed several cases authorised by the neighbourhood secretary and later on the celebration was ruined (for lacking authorisation) by the Renamo delegate or by the administrative unit, or vice-versa. One of such conflict was brought to the community court of Cerema and was analysed by us. The court focused on the unjustified damage caused to the families and neighbourhood by the destruction of the rites, but it was unable to provide a solution other than calling upon the parties in conflict to be reasonable and find a solution in respect of the needs and expectations of the people.

But the segmentation of the political sphere penetrated the private space, especially in Inguri. As a woman described:

Renamo came to the parampa I was invited to, and forbade the other woman to sing - because there is a specific song to dance always sung by two women. Before, it used to be two representatives of Frelimo who sang, but because the municipality changed [political] colours, the woman from Frelimo did not have the right to sing. ${ }^{74}$

\section{Conflict and Segmentation on the Traditional/Traditional Mix}

The goal of Decree 15/2000 was to identify 'the very own chief' 75 as the interface between the state and the community. However, the figure of the 'chief' remains ambiguous, since the Decree sought to incorporate in a uniform law different forms of traditional rule and social organisation existing in Mozambique. Article 1 of the Decree clearly states that 'community authorities are the traditional chiefs, neighbourhood and village secretaries and other leaders who have been legitimised as such by the respective communities'. Further on, the Decree mandated local government to consult and work in cooperation with these authorities in various functions re- 
lated to development, but the Decree did not specify what constituted a 'community' nor did it institute clear mechanisms for its 'recognition'.

Later legislation ${ }^{76}$ established in more precise way the distinction between traditional authority and secretaries, thus downgrading the myriad of instances present to a double category - the local representatives from colonial times and the leadership introduced by Frelimo. The former are 'people that assume and exercise leadership according to the traditional rules of their community', while the latter are 'people that assume leadership by being chosen by the population of the neighbourhood or village to whom they belong' (Art. 1 of Diploma 80/2004).

In a sentence, the difference is in the process of selection, be it through direct elections (in the case of secretaries) or their 'ancestral' legitimacy and knowledge, for the case of traditional authorities. The diploma refers still to a third category 'of other legitimised leaders': people that exercise some economic, social, religious or cultural role accepted by the 'social group' to whom they belong. Law 11/2005 reinforces the special status of traditional authorities and secretaries. This Law stipulates that the 'special rights' of these authorities 'be recognised and respected as representatives of their local communities; to participate in local councils; to participate in official ceremonies locally organised by administrative state authorities (Art. 108). That implicitly calls for the inter-community legitimacy of these leaders to support state decisions at the local level. This is explicitly acknowledged in Articles 106 and $107,{ }^{77}$ which define the duties of these community authorities. These articles enlarge the scope of the interaction between the state and these 'local authorities', which includes activities in support of the state events in the area, work activities in common areas, conflict resolution and support of community courts, tax collection, judicial proceedings, policing, land distribution, public health and sanitation, public education, mobilisation of the population for participating in development projects, etc.

The recognition of community authorities played out differently in Angoche. As described above, in pre-colonial times, dispersed settlement ruled by paramount chiefs with a high degree of autonomy dominated in the region.

The Portuguese colonial administration, in order to administer local populations through the intermediary of hereditary, traditional chiefs, was obliged to construct hierarchies between settlements' heads, which previously did not exist. With independence, Frelimo introduced Grupos Dinamizadores, neighbourhood secretaries, but the local socio-political system continued to perform semi-clandestinely (Geffray 1990; Conceição 2006).

With the re-introduction of 'community authorities', the conflict and confusion over control surfaced. As the Angoche District Administrator 
recognised, 'it is a question of power; now we have a conflict between the régulo and the local authority [secretaries, and other administrative staff]' ${ }^{78}$

Some people demonstrated no interest in resuscitating the hierarchy of chiefs - régulos - through which the Portuguese had governed in colonial times. They noted that chieftaincy was disrupted, that there were conflicts over territories, over hierarchies and titles. In the very words of a community court judge, 'the régulos have ceased to function a long time ago. I even forget they exist. The state eliminated them, because there was no need for them.' ${ }^{79}$ The same opinion was also expressed by other community judges interviewed in Angoche. ${ }^{80}$ Others saw benefits in chiefs gaining recognition largely due to their access to other forms of knowledge, beyond that of the secretaries. In 2003, for example, in Inguri, the Director of the Administrative Unit explained that Régulo Likwhuari was 'involved in many activities, such as sacred ceremonies, ritual of initiation. Sometimes people resort to him to solve problems, such as social conflict and land demarcation of land plots in the neighbourhood' ${ }^{81}$ For others still, it remained a political question, and a search for authenticity, as one of the Renamo delegates defended:

The community has to be ruled by itself. We have always struggled for the existence of traditional authority. Traditionally, we had a form of power which was ours. It was the colon that changed the name to régulo. ${ }^{82}$

Almost with no exception, government officials pressed for the presence of 'community authorities' in Angoche district, with some of them expressing nostalgia for the late colonial model of administration. They cited the régulos utility in collecting taxes locating criminals, solving disputes, acting as messengers. ${ }^{83}$ Even an important Police officer remarked that 'where the régulo exists, it is easier to work, because we feel that it is a person with power. And they are more powerful than the neighbourhood secretaries, of course' ${ }^{84}$

For the defenders of local decentralisation, elections for the local municipality were an answer to enlarge the participation by citizens at local level; however, Frelimo’s project did not contemplate the presence of régulos or other instances of 'traditional authority'. During the various visits paid to Angoche, Régulo Likwhuari complained that he had not been recognised formally by the state. In his own words:

A long time ago I had two houses, one built with my own money I earned fishing; the other was offered by the Portuguese administration, because I was a régulo. Sometime after independence, the government confiscated my main house [the one the colonial government had built]. ${ }^{85}$ Later on they gave it back to me. But with the municipal elections, they removed me from there again [in 1998]. I am nobody. Where there is no municipality, there is no problem. In the district the régulos have power. ${ }^{86}$ 
In the city, the secretaries continued to perform their activities as before, maintaining a strong complicity between the city-elected administration and Frelimo party. As remarked by the secretary of one of Angoche's neighbourhoods, 'in 1989 I became the party secretary in this neighbourhood, and I am still the party secretary today'. Further on, he would add: 'In the administrative unit we belong to, there are 18 neighbourhoods that correspond to 19 party cells' ${ }^{87}$ In short, the recognition of régulos did not occur during the term of Frelimo's mayor, that is, no régulo had been recognised in the city, while in the nearby district the process was taking shape. ${ }^{88}$

When Renamo won the elections, one of their policies was to recognise traditional authorities. As expressed by a Director of an administrative unit in Angoche:

If the central government wanted the régulos to be in function, they had already recognised them here in Angoche long ago. But no! Who is fighting for the régulos is Renamo, and it explains the long delay in recognising them here in Angoche. ${ }^{89}$

Once in power, Renamo initiated the process of legitimisation and recognition of régulos in Angoche, following the directives of the Ministry of State Administration and applying them to the municipality. As expressed by a municipal official, 'We received those documents ${ }^{90}$ and we have started the process of legitimisation of these community authorities. We do everything according to the law'. ${ }^{91}$

The régulos themselves were not above party politics; also, conflicts were common within and among lineages. Such conflicts were brought to the fore by both sides - Renamo and Frelimo - in an effort to recruit chiefs as a means of extending their (government) authority. This was happening in several neighbourhoods, such as in Cerema. Up to 2004, the Régulo of Hékeréke - with whom the city municipality would dialogue - was Matias Alberto Omar, himself a Frelimo member. ${ }^{92}$ However, when Renamo came to power, the one recognised by the Municipality became Régulo Muhálà, a strong Renamo supporter. This political segmentation became evident. In the words of the then Angoche state attorney:

In the beginning the régulos were more supportive of Renamo, which claimed to defend their interests. But with the changes that took place, Frelimo conquered several of them. And a division happened - now some are known to be with Renamo, others are on the opposite side, with Frelimo. And they act according to their political interests' ${ }^{93}$

Because the certification of traditional authorities by the Municipality did not entail the prerogatives granted by the central government, the status of such traditional authority became rather ambiguous, ${ }^{94}$ and another segmentation 
emerged as a result. On one side, traditional authorities in the district supposedly close to Frelimo for having been legitimated by the central government, and, on the other side, traditional authorities in the city supposedly close to Renamo for having been legitimated by the municipal government.

The colonial three-tier hierarchy of 'traditional authority' in Angoche (régulo, chefe de grupo de terras, chefe de povoação) was imposed, whether or not it fitted the local reality. The Decree 15/2000 and the subsequent legislation did not open space for diversity. As a result, several leaders remained excluded. For example, the title of mwénè did not fit the existing structure. As a solution, Renamo administration transformed some of them into 'community authorities', resulting in competing authorities over the same jurisdiction. ${ }^{95}$ Together with the elected administration, this particularly segmented component of 'local authority' sought to engage with other administrative instances in solving the problems of Angoche. In the words of the Régulo of Puli, 'today we are seven régulos in the Municipality, but we do not know very well how to work. I am not sure about my function. And then, there are the community leaders too... ${ }^{96}$

\section{Conflict and Segmentation on the Traditional/Modern Mix}

The political segmentation of the base-level administration reached another level with polarisation around the traditional authorities. In this case, the segmentation occurred between traditional institutions brought about by a modern political conflict (Renamo versus Frelimo). Moreover, it did not take place within the state, as in the previous case, but rather on a contact zone between the state and the community.

The segmentation - resulting from the pattern of conflictual parallel construction of the local state - produced yet another segmented administrative and judicial structure. Seeking to substitute the posts created and filled in with Frelimo supporters, at the level of the neighbourhoods, Renamo created its own structure, aiming at replacing the secretaries with delegates. However, this only segmented even more the Angochean society: 'now, in each area we have the secretaries from Frelimo, and there are also the delegates of Renamo. Both seek to solve problems in their own neighbourhoods. It is very confusing', ${ }^{97}$

The question of the community police became particularly evident. The councils of community police were introduced in 2000, as a means to monitor crime and bridge the community with the state police, by implementing citizen's voluntary participation. In 2003, several councils of community police were active in Angoche (Meneses 2007:34-35). Once again, the interference of Frelimo was notorious. For instance, in one of Angoche's neighbourhoods, members of community police reported that they had been 
chosen 'by the secretary and the police commissioner' ${ }^{98}$ Renamo opted to create a community police parallel to the existing one. ${ }^{99}$ The community police functioned in close association and under the supervision of the secretaries; therefore they were perceived as belonging 'not to the municipality [Renamo], but to the nation [Frelimo]'. ${ }^{100}$ In the words of the Administrator of Angoche, this became a critical political problem, since 'the various administrative units had decided that the community policies could only include Renamo people'. ${ }^{101}$

Gradually, one witnessed the emergence, on the side of Renamo, at each administrative unit, neighbourhood delegates, community police and traditional authorities certified by Renamo; on the Frelimo side community courts, neighbourhood secretaries and community police, and traditional authorities certified by Frelimo.

The rich network of dispute resolution mechanisms existing before and operating cooperatively, was thereby fractured, the cooperative coexistence replaced by a competitive one and the people were led to choose between one of the segments of the network. As noted by one of the directors of the administrative units in Angoche from Renamo, the political competition had fractured the society at multiple levels:

When we say that this administrative unit belongs to Renamo, it means that Renamo won. Before, Frelimo was here and spoke loud, and Renamo was silenced. Now, the secretaries have to accept that there is another party, but they don't accept. The secretaries go around and keep working as before, solving conflicts, issuing declarations. I tell them that now how in this municipality who has to solve the problems of the populations are the régulos. But the secretaries won't allow it. When the régulo is reunited with the population, solving the problems, the secretaries show up and destroy everything. They say 'we are the ones who rule, we are from the nation, we don't recognise Renamo'. And we have to carry on working with many difficulties, being prosecuted by their community courts and their community police. ${ }^{102}$

By 2006, the segmentation had achieved new contours. Frelimo's secretaries continued to work, in parallel with Renamo's secretaries, as recognised by several of the interviewees:

The problems of the people are very serious here, because I am a secretary, but there is the régulo and the community leader, they also want to solve the problems here. And then comes the senhor secretário, the old one, from the government, as says he also wants to work. And he forbids the others [to work], he says we have no right to solve conflicts in this neighbourhood. ${ }^{103}$ 
The proliferation of administrative and dispute resolution mechanisms, rather than increasing the horizon choices of the people, diminished it. The most telling dysfunction of these segmentations became the disputes among different dispute resolutions institutions, through their leaders, involving insults, threats and sometimes even physical aggression, disputes that even had to be taken to the police or the district courts for settlement. In other words, the institutions in charge of settling disputes became a source of conflict themselves, in disputes created by them to be settled elsewhere.

\section{Conflict and Segmentation in the Secular/Religious Mix}

The segmentation of dispute resolution mechanism has still another dimension which is another contributing factor to the dual local state. This dimension concerns the secular/religious binary or mix, and refers to the Islam.

The influence of Islam in its multiple conceptions is a reality in Angoche. These three divergent conceptions of Islam are the Swahili Africanised Islam, the Sufis, and the 'modernist' Islamists, also known as Wahabbis (Bonate 2007a). This diversity while being at that instance a font of tension, it was for a long time a local resource, a variety of options offered to the Angocheans to fulfil their religious aspirations or to settle the disputes among them.

Neither as a cultural imprint nor a dispute resolution mechanism does Islam, in its different currents, operate in isolation. It is part of a complex constellation of political cultural legal forces operating at the local level. Such constellation comprises the municipal administration, the Frelimo/Renamo local cadres, traditional authorities of various kinds and a panoply of submunicipal authorities, some surviving from the revolutionary period (19751985), others newly created. In the case of Islam, there are also global and regional influences conditioning its development and internal diversity (Santos 2006). While the previous lines of segmentation occurred either within modern institutions (the case of administrative units versus community courts or community police versus community police), in a mix or traditional/traditional institutions (case of the 'new' and 'old' régulos), or in a mix of traditional/ modern institutions (the case of dual legitimation of 'community authorities'), this last segmentation concerns the line secular/religious which occurs in a contact zone that is a continuum between the state and the non-state as polar positions, and is situated in a position close to the non-state pole. Moreover, this segmentation has a more complex causation than the others. On the one hand, some of its factors date back to the colonial and the pre-colonial period. On the other hand, besides national factors, global factors are at work, in this case Islamism. The impact of these factors, however, was decisively conditioned by the political polarisation Frelimo/Renamo as it happened in the previous segmentation. 
As we said in the beginning, Islam has a long and strong presence in Angoche. Islam leaders have always been an integral part of the network of dispute resolution institutions, particularly in the domain of family disputes. Through their participation in chiefly lineages, they became traditional authorities with functions that combined religious and secular tasks. 'In the past, before Frelimo arrived, the family problems were all solved with the help of the xehe'. ${ }^{104}$

Since late nineteenth century, the Africanised Islam co-existed with the Sufi orders. The tensions among them had not so much as religious base, as an ethno-cultural base, as the Sufi orders were for a long time controlled by Indo-Africans who were descendent of the Gujarati Sunni Indian immigrants and local African women (Bonate 2007a:146-147; Bonate 2007b:56; Meneses 2008). More recently, in the 1960s, another current of Islam, the Wahabbis, has emerged and gained prominence with strong connections with Sudan and Saudi-Arabia. The coexistence of these three currents of Islam - Africanised Islam, Sufi orders and Wahabbis - has been a source of tension for some time.

In the struggle for social visibility and political leverage, different Islamic organisations were created. As described by Bonate (2007a), the Wahabbis took advantage of ban on traditional and religious authorities to design an Islamic association that would eliminate all their historical rivals. When the ban was lifted, in 1981, the Conselho Islâmico de Moçambique was established in Maputo, with the assistance of the government. The formalisation of this Council was a great victory for the Afro-Indian Wahabbis, since the northern Mozambican Sufi-based Muslims leadership was not involved (those of Angoche were not even consulted). Probably for their modern outlook, their refusal of traditionally based Islam and their university degrees and Middle Eastern Islamic culture, Frelimo showed its preference for the Council as the legitimate representative of all the Islam in Mozambique.

Two years latter, in 1983, Maputo Muslims who disagreed with the Wahhabis created their own national organisation, the Congresso Islâmico de Moçambique. The Congress united most of the pre-colonial associations, including Sufi Orders.

The competition between the two organisations for government support, as well as for the funding of international Islamic NGOs is installed since then. ${ }^{105}$ As described by a Shaykh, himself a member of the Council, this segmentation on religious grounds was very violent:

I had problems with a xehe, because he belongs to the Congresso and wanted me to be part of the Conselho. He hunted me down seeking to arrest me, because he wanted everybody in Angoche to belong to the Congresso'. In his own words, the conflict expressed the debate on the nature of Islamic 
authority, especially with regard to religious rituals: the difference lies in the study of the Koran. Now we have different mosques and in each we pray in a different way. ${ }^{106}$

But this tension intensified enormously due to the Renamo/Frelimo polarisation. While many of the Afro-Islamic local leaders were considered to tend toward a pro-Renamo position, the Council was vocally pro-Frelimo: 'they even have elected a deputy to the Parliament', murmured a member of the Marudia Mosque. ${ }^{107}$

This situation has been the source of continual frustration and resistance to the alleged racial and cultural discrimination perpetrated southern Wahhabis, Afro-Indians, and Indians, in alliance with Frelimo. The Congress itself, purported to be politically neutral, competed with the Council for Frelimo favours (Bonate 2007a:145-146). ${ }^{108}$ Probably for this reason, a group of pro-Renamo young affiliates of the Council - most of them with religious training at universities abroad - spilled and created a new alternative organisation, the Alh Al Sunnah. ${ }^{109}$

When the Renamo won the elections, the tensions among the different Islamic organisations rose in Angoche. Traditional Muslim leaders, always seen as 'unmodern' or as syncretised with African traditions and chiefly structures, had always resented their failure to establish their Islamic legitimacy and the discrimination against them by the Southern pro-Frelimo Wahabbis, Afro-Indians and Indians. Renamo's local victory was seen as an opportunity to strengthen their traditional power and to establish their Islamic legitimacy. Some of them who identified with Frelimo moved to Renamo, such as the case of Shaykh Hasan Ali 'Concavo' ${ }^{110}$ On the other hand, the Wahabbis, benefiting from the financial support from foreign sources, intensified their social action and religious proselytism.

I studied the Koran in Sudan. These old xehes you have spoken too, they are backwards, they know nothing, what they lecture is incompatible with the 'truth'. We are the true interpreters of the Kitabu'. ${ }^{111}$

Further on, when asked about his political goals one of the members of the Alh Al Sunnah stated:

I do not agree with Frelimo or Renamo. Renamo used to understand us, but they also do not want to recognise the power of Shari'a. And that is the wish of Allah. ${ }^{112}$

In this intensified competition between different Islamic organisations, one detects another manifestation of the hyper-politicisation of social life caused by the Renamo/Frelimo polarity, with the consequent segmentation in the secular/religious network of services. 


\section{Conclusion}

Institutional mechanisms (be it representative democracy, or various institutions and instruments set up by local government to enhance participation) are currently quite problematic in Mozambican municipalities, and the city of Angoche in particular, whose citizens resort to various means in order to solve their problems, to be heard.

While analysing local development reforms in Mozambique, several scholars have pointed out how the convergence of interests between state institutions and officials interested in firmly controlling the reforms and donors inclined to impart technocratic solutions, in a situation in which resources are scarce, inevitably leaving immense power to the few holding state and administrative institutions (Grest 1995; Harrison 1996; Alexander 1997; Santos 2006). The Angocheans, with no pedagogies of appropriation of democratic citizenship, where left at the mercy of the parties.

Unable to eliminate, replace or control the existing administrative and dispute resolutions institutions, the Renamo municipal government, in power between 2003 and 2008, decided to duplicate such institutions through the community courts, neighbour delegates or traditional authorities, and community police. In doing this, the municipal government followed a strategy indeed very similar to the one it criticised when adopted by Frelimo, that is, the over-politicisation of the public administration. A dual state emerged at the local level with obvious costs for the population, confused before parallel institutions and without any clue as to their relative efficacy to solve their problems or to settle their disputes.

In 2006, and probably as a response to the loss of control over the municipalities now ruled by Renamo, Frelimo initiated a process of new territorial definition, aimed at 're-organising' the municipal limits. At the same time, and claiming that the state has responsibilities and obligation in terms of territorial management, the Ministry of State Administration had begun introducing the figure of 'state administrator' at the municipal level. Although the Minister maintains that the municipalities have administrative autonomy, these officials, supposed to function in those spaces, are accountable to the central government.

The article seeks to identify some of the structural and contextual constraints that may be responsible for this lack of bottom-up dialogue. Some of the conclusions are that the highly politicised spheres of power lead to the development of patterns of clientelism and dual party system at the local level. This government fragmentation at municipal level is an important factor in the failure of participatory processes, for not allowing for a broader engagement of people in the local government on the best ways of meeting social needs. 
In Mozambique, one of the specifics of the democratic system present is that it represents a political solution for co-habitation between major political protagonists. The democratic solution that resulted from the peace agreements - the introduction of multipartidarism - was a primary tool for peace making in Mozambique. But this does not coincide with the need for democratisation and political participation. In times of peace, political confrontations continue, as the parties function under the logic that the party space corresponds to the sphere of the state interventions. In short, the party is the state (and the militants assume this position once in power).

What was the political meaning of this dual local state emerging from competitive administrative creation and network segmentation? The election of a Renamo municipal government was celebrated by different observers as a signal of democratic consolidation. But what type of democracy is this? Are we before a new type of democracy, a two single-party democracy? The case of Angoche suggests that between 2003 and 2008 the local political system was based, not on a multi-party democracy, but rather on a twosingle party democracy.

Participation does not necessarily allow people to raise other positions and often straitjackets discussion into consensus oriented outcomes. A more democratic approach to participation would not fear debate but rather encourage and facilitate it. With the transformations that the Mozambican cities have known since independence, decision making is not devolved to the most local scale. However, participation often happens at the local scale of the ward. The interaction between these scales is key to determining the degree to which people influence policy. Finally, one should analyse whose agendas are represented and discussed at the municipal level. As the data analysed here suggest, reflection on local level participatory meetings is required in order to determine whether the most marginalised people are being accessed. Are dissenting voices outside of participatory forums seen and heard as valid? A danger of formal spaces of participation is that they effectively shut down other initiatives to engage the government critically. Together, these questions are intended to allow for critical reflection on the democratic value of participation, and probably will help in explaining the effort put in by all parties in the 2008 municipal election, an election won by Frelimo in 42 municipalities. The only exception was Beira - Mozambique’s second larges city, won by an independent candidate. The victory of Uria Simango suggests that at local level, democratic participation can mobilise independent, but legitimised political leaders, outside the major political parties. Will that be a solution to deadlock of the dual party scheme? The future will tell us. 


\section{Notes}

1. This paper draws upon both individual and collaborative research undertaken by the authors.

2. In 2006, the central Government of Mozambique allocated, for the first time in the history of independent Mozambique, a percentage of the state budget correspondent then to 7 million of meticais (now 7 thousand of new meticais, about US\$ 300,000) to each of the country's district.

3. The concept of heterogenous state has been coined by Santos, 2006.

4. Frelimo has been the main political force in the country, even after the introduction of a multiparty system in 1994, having won all the presidential and legislative elections.

5. Integrating AMETRAMO (Mozambique Traditional Healers Association), PROMETRA (Organisation for the Promotion of Traditional Medicine), among others.

6. Interview with Régulo Shale Abdallah Yussufo - Likwhuari (Angoche city), 30 September 2003, and 28 August 2004.

7. That is, the régulos were not a social category exclusive of the rural world.

8. The first Estatuto do Indigenato (corresponding to the Native Codes in neighbouring British colonies) contained the foundations of the Portuguese 'native policy'. Its first version was approved with the force of Law in 1926, but the Estatuto knew several changes, until it was abolished in 1961.

9. See interview with Régulo Likwhuari, Angoche, 2004.

10. Articles 4, 26 and 36 of the 1975 Constitution of Mozambique.

11. One criticism leveled against this form of local administration was that the centrally appointed chairperson or administrator deprived the city or district council of its autonomy. Another criticism against the executive councils was that they were charged with the responsibility of directing, coordinating and controlling subordinate directorates and services without supporting instruments and resources to ensure that their decisions were implemented. See Resolução Geral - $1^{a}$ Reunião Nacional sobre Cidades e Bairros Comunais (Maputo, Imprensa Naciona, 1979).

12. Law 5/78 (of 22 April 1978) that abolished the colonial forms of local government (Câmara Municipal). In their place, Mozambique government introduced the 'executive council' (Conselho Executivo) as the executive bodies of the cities and district assemblies (Law 7/78 of 22 April 1978).

13. Decree n. 6/78 of 22 April 1978.

14. On this subject, see, for example, Geffray 1990; Vines 1991; Chingono 1996; Hall and Young 1997; Cabrita 2000; Hanlon 2001 and Dinerman 2006.

15. The 1990 constitution defined the tasks of the local state organs as follows (Article 185):

1. The local organs of the state shall organise the participation of citizens in solving the problems of their communities and shall promote local development.

2. The strengthening of local organs shall serve to reinforce democracy and shall contribute to national integration and unity. 
16. Currently (2009) there are 43 municipalities in Mozambique.

17. Interview with an official of Angoche District Administration, 27 August 2004.

18. Interview with Fernanda Namikuto, 29 September 2003; Interview with Sabino Hassane, 27 September 2003.

19. Interview with Alberto Omar Assane, Angoche District Administrator, 23 August 2004.

20. Among several important publications on this subject, see Lupi 1907; Massano de Amorim 1911; Mello Machado 1970; Hafkin 1973; Mbwiliza 1991; Newitt 1995; Pelissier 2000; Bonate 2003.

21. Mainland administration.

22. This was a broader conceptual category, which included not only the 'metropolitan' Portuguese, but also Indian, African and mixed-race subjects of the Portuguese Crown. See Hafkin 1973:xviii; and Pélissier 2000, vol. 1:55-56.

23. Interview with several régulos of Angoche - October 2003 and August 2006.

24. The 'anhyapakho' (sing. nhapakho) are the descendants of the 'first' inhabitants of Angoche. The Shirazi ruling clan of the anhyapakho has enjoyed dominant positions, because the members had escaped the Portuguese ravages of the sixteenth century and took over the traditional Swahili trade on the decline of the leading Swahili settlements of northern Mozambique (Newitt 1972a).

25. The term Maca would identify the Muslims, considered 'civilised', vis a vis those to be enslaved - the makhwa, considered savages). On this subject, see Lupi 1907:70, 106, 178-9; Hafkin 1973:36, 82; Bonate 2006:142.

26. Xehe correspond to the africanisation of Shaykh. In the case of the Sufi orders it is used to refer to a religious leader (Pinto de Carvalho 1988:65). However, more often this title is used to refer to a Muslim man 'very respected and with a profound wisdom [about Islam]' (interview with a Xehe, Angoche, 1 October 2003).

27. Interview Régulo Likwhuari, on 28 August 2004.

28. Also, Interview with Fernanda Namikuto, 29 September 2003.

29. Angoche became a city in 1970 .

30. Interview with a Régulo, 4 October 2003.

31. Interview with D. Amina, Inguri - Angoche, 8 October 2003 and interview with a neighbourhood secretary, 6 September 2003. The quarteirões were also subdivided into smaller unit, headed by the 'chief of 50 or 10 houses'.

32. The Constitution of 1990 created a new judicial organisation, where the lower level courts, which judged according to the Constitution and the local customs and norms, became separated from the formal court system. Thus, the community courts created by Law $n^{0} 4 / 92$ (of 6 May) became outside the formal judicial organisation (Santos 2006:49, 56). Interview with the collective of judges of the Community Court of Angoche city, 27 August 2004.

33. Interview with a Community Court Judge in Angoche, 8 October 2003.

34. Interview with deputy Presiding Judge of a Community Court, Angoche, 13 October, 2003. 
35. Interview with Angoche Administrator, 23 August 2004, and interview with the town mayor, Alberto Omar, 23 August 2004.

36. Interview with Fernanda Namikuto, Angoche, 28 August 2004.

37. Interview with the presiding judge of a Community Court of Angoche, 4th October 2003. The judge reported two cases: one involving the previous presiding judge of the court, who had been bribed several times, and the case of a neighbourhood secretary, that had land plots belonging to other people. A similar situation has happened with a previous presiding judge of a Community Court in the city (collective interview with the judges, 30 September 2003).

38. Interview with member of the Marudia Mosque - Inguri, 4 October 2003.

39. Law 3/94 of 13 September 1994.

40. Law 2/97 of Local Municipalities - designed as 'autarchies' (of 18 February 1997). It was followed by Law 11/97 of Municipal Finances (31 May 1997). Together these laws constituted the national legal framework for giving municipalities extensive administrative and financial autonomy. The municipal revenues include local taxes, and other fees.

41. The ban of religious institutions had been lifted in the 1980s.

42. Headed by the Ministry of State Administration, in charge of the dossier on community authorities. This process is analysed in detail in Kyed and Buur 2006.

43. Decree 15/2000 of 20 June 2000 and Diploma 107-A/2000 of 25 August 2000. These two pieces of legislation were passed only by the Council of Ministers.

44. AWEPA Mozambique Political Process Bulletin 21 (21 July 1998).

45. Interview, 29 September 2003.

46. In 2004 there were four complaints in the District Court against.

47. Interview with the Director of Unidade Autárquica do Inguri, on 13 October 2003.

48. Collective interview with the judges from a Community Court, 31 September 2003.

49. Interview on 13 October 2003.

50. More recently, in July 2008, the Community Courts of another northern municipality considered a stronghold of Renamo - Nacala - went on strike, claiming better financial conditions from the state.

51. Interview with a Presiding Judge of a Community Court, 30 September 2003; and interview with the collective of judges from another Community Court of Angoche 31 September 2003.

52. Interview, 30 September 2003.

53. All of them Frelimo members - Interview, 3 October 2003 and another interview on 3 August 2006.

54. Interview with a former Frelimo official at the Unidade Autárquica, August 2006.

55. Interview with the Secretary of Angoche sede, 15 October 2003.

56. Permanent representatives of INASS in the neighbourhoods. 
57. Interview with Fernanda Namikuto, 26 August 2004.

58. Interview with a Director of a Unidade Autárquica, 24 August 2004.

59. Interview with Alberto Omar, mayor of Angoche, 30 August 2004.

60. Interview with a Renamo municipal official, 23 August 2004.

61. Interview with a municipal official from Renamo, 26 August 2004.

62. Interviewed in 3 August 2006.

63. Interview, 24 August 2004.

64. Interview with a Judge of a Community Court of Angoche, 27 August 2004.

65. Interview with the Director of the Unidade Autárquica of Inguri, 23 August 2003.

66. Interview with a Judge of a Community Court of Angoche, 27 August 2004.

67. Interview with the Director of the Unidade Autárquica, August 2004.

68. Interview, 24 August 2004.

69. Interview with Alberto Omar Assane, Administrator of Angoche (local state representative), 23 August 2004.

70. Observation in Inguri - Angoche, 29 October 2003.

71. The 'parampara' became the symbol of girl's ritual of initiation, formalised by Frelimo in the early years of independence in Angoche. As a symbol of entrance into adulthood, this ritual attracts large groups of women, who want to celebrate their womanhood. It is easily identified by the low sound of drums that accompanied it.

72. Organização da Mulher Moçambicana - Mozambican Women’s Organziation.

73. Interview, 25 August 2004.

74. Interview in August 2004.

75. Interview with an Administration officer in Angoche, 27 August 2004.

76. Such as Ministerial Diploma 80/2004 of 14 May 2004, regulating the articulation between autarchies and community authorities, and Law 11/05 of 10 June 2005, regulating the functioning of local state organs. It should also be pointed out that the 2004 Constitution recognises, for the first time, the figure of 'traditional authority' (Art. 118).

77. These duties are quite similar to the one established in Decree 15/2000. The Law also stresses that among their special rights these leaders are entitled to: display the symbols of the republic; to wear their official garment; to be paid (receive) a subsidy depending upon the amount of taxes collected by them (Art. 110).

78. Interview with the Angoche District Administrator, 15 October 2003.

79. Interview with a judge of the Community Court of Angoche city, 28 August 2004.

80. Interview with the judges from several Community Courts of Angoche, on 1st October and 14 October 2003.

81. Interview with Orlando Abuque, 13 October 2003.

82. Interviewed in 13 October 2003.

83. Interview with an administration official, 27 August 2004. 
84. Interview, 2 October 2003.

85. Currently the Unidade Autarquica of Inguri functions in his 'official' house.

The community court and the community radio were also based there in 2004.

86. Interviews with Régulo Likwhuari, 30 September and 15 October 2003 and 28 August 2004.

87. Interviewed in 6 September 2003.

88. The information made available from the District Administration revealed that up August 2004, 41 régulos has been legitimised by the population in Angoche District (surrounding Angoche city), of which 35 had been recognised by the state. By 2006 all of then had already been recognised by the state.

89. Interview, 24 August 2004.

90. Ministerial Diploma 80/2004 and Law 11/05, that recognised 'community authorities' mostly in rural areas.

91. Interview with a Director of a Unidade Autárquica, 2 August 2006.

92. Interviewed on 4 October 2003.

93. Interview on 25 August 2004.

94. Interview with an Administrative officer, Angoche, 5 August 2006.

95. Interview with a Community Leader, 9 August 2006.

96. Interview, 9 August 2006.

97. Interview with a Judge from a Community Court of Angoche, 27 August 2004.

98. Interview with members of the community police, 14 October 2003.

99. Interview with a Renamo municipal official, 23 August 2004.

100. Interview with a Community Leader, Angoche, 9 August 2006.

101. Interview with the Angoche District Administrator, 23 August 2004.

102. Interview, 24 August 2004

103 Interview with a secretary in Angoche, 9 August 2006.

104 Interview with shaykh Amisse Hassan, Horta, 29 September 2003.

105. Interview with member of the Marudia Mosque (from the Congress), 5 October 2003.

106. Interview, 29 September 2003.

107. Interview with a member of the Marudia Mosque (from the Congress), 5 October 2003

108. Interview with members of the group Ahl Al-Sunnah, 5 October 2003.

109. Ibid.

110. Interview in 26 August 2004.

111. The Book, meaning the Koran.

112. Interview in 28 August 2004.

\section{References}

Abrahamsson, H., Nilsson, A., 1997, The Washington Consensus and Moçambique. Götegorg: Chalmers Reporcentral.

Alexander, J., 1997, 'The Local State in Post-War Mozambique: Political Practice and Ideas About Authority', Africa: Journal of the International African Institute 67 (1): 1-26. 
Alves, A.T., Cossa, B.R., 1998, Guião das Autarquias Locais. Maputo: Ministério da Administração Estatal and GTZ.

Amaro Monteiro, F., 1993, Islão, o Poder e a Guerra: Moçambique, 1964-1974, Porto, Centro de Estudos Africanos da Universidade Portucalense.

Bledsoe, C.H., 1980, Women and Marriage in Kpelle Society, Stanford: Stanford University Press.

Bonate, L.J.K., 2003, 'The Ascendance of Angoche: The Politics of Kinship and Territory in Nineteenth Century Northern Mozambique', Lusotopie 2003:115-140.

Bonate, L.J.K., 2006, 'Matriliny, Islam and Gender', Journal of Religion in Africa, 2 (36), 139-166.

Bonate, L.J.K., 2007a, 'Roots of Diversity in Mozambican Islam', Lusotopie, XIX (1): 129-149.

Bonate, L.J.K., 2007b, 'Islam and Chiefship in Northern Mozambique’, ISIM Review, 19:56-57.

Braathen, E., Jørgensen, B.V., 1998, ‘Democracy without People? Local government reform and 1998 Municipal elections in Mozambique’, Lusotopie 1998: 31-38.

Brito, L., 1988, « Une relecture nécessaire: la genèse du Parti-État Frelimo », Politique Africaine, 29, 15-27.

Cabrita, J., 2000, Mozambique: The Tortuous Road to Democracy, Basingstoke: Palgrave.

Capela, J., 2002, O Tráfico de Escravos nos Portos de Moçambique, 1733-1904, Porto: Afrontamento.

Carbone, G.M., 2005, ‘Continuidade na Renovação? Ten Years of Multiparty Politics in Mozambique: Roots, Evolution and Stabilisation of the Frelimo-Renamo Party System', Journal of Modern African Studies, 43 (3): 417-442.

Chingono, M.F., 1996, The State, Violence and Development: The Political Economy of War in Mozambique, 1975-1992, Aldershot: Avery Ashgate.

Conceição, R., 2006, Entre o Mar e a Terra: situação identitária do norte de Moçambique, Maputo: Promédia.

Cuahela, A., 1996, Autoridade Tradicional em Moçambique, Maputo: Ministério da Administração Estatal.

Cuereneia, A., 2001, The Process of Decentralisation and Local Governance in Mozambique: Experiences and Lessons Learnt. Paper presented to the UNDP (at http://www.uncdf.org/english/countries/mozambique/local_governance/ technical_review_reports/ACuereneia.php, accessed on 14th May 2005).

Dinerman, A., 2006, Revolution, Counter-revolution and Revisionism in PostColonial Africa: The Case of Mozambique, 1975-1994, London: Routledge.

Eickelman, D.F., Piscatori, J., 2004, Muslim Politics, Princeton: Princeton University Press.

Feliciano, J.F., 1998, Antropologia Económica dos Thonga do sul de Moçambique. Maputo: Arquivo Histórico de Moçambique.

Francisco, A.A.S., 2003, 'Reestruturação Económica e Desenvolvimento’, in B. Santos and J.C. Trindade, eds., Conflito e Transformação Social: uma Paisagem das Justiças em Moçambique, Porto: Afrontamento, volume 1: 141-178. 
Geffray, C., 1990, La Cause des Armes au Mozambique: anthropologie d'une guerre civile, Paris: Khartala.

Grest, J., 1995, 'Urban Management, Local Government Reform and the Democratisation Process in Mozambique: Maputo City 1975-1990', Journal of Southern African Studies, 21 (1): 147-164.

Guambe, J.M.E., 1998, 'Historical Evolution of Decentralisation in Mozambique’, in A.M. Silva (ed.), Decentralisation and Municipal Administration, Maputo, Friedrich Ebert Stiftung, pp. 13-21.

Hafkin, N.J., 1973, Trade, Society, and Politics in Northern Mozambique, c. 17531913, Ph.D. Thesis, Boston University, 1973.

Hall, M. and Young, T., 2000, Confronting Leviathan: Mozambique Since Independence, Athens: Ohio University Press.

Hanlon, J., 1997, Guia Básico Sobre as Autarquias Locais, Maputo, Ministério da Administração Estatal e AWEPA.

Hanlon, J., 2001, Mozambique: Who Calls the Shots? London: James Currey.

Harrison, G., 1996, 'Democracy in Mozambique: The Significance of Multi-party Elections', Review of African Political Economy, 23 (67): 19-25.

Kyed, H.M., Buur, L., 2006, 'New Sites of Citizenship: Recognition of Traditional Authority and Group-based Citizenship in Mozambique', Journal of Southern African Studies 32 (3): 563-581.

Lundin, I.B., 1998, 'Traditional Authority in Mozambique', in A.M. Silva (ed.), Decentralisation and Municipal Administration, Maputo, Friedrich Ebert Stiftung, pp. 33-42.

Lundin, I.B., 2000, 'Africa Watch: Will Mozambique Remain a Success Story?’, African Security Review, 9 (3) (at http://www.iss.co.za/pubs/ASR/9No3/ AfricaWatch.html, accessed on 4th May 2006).

Lupi, E.C., 1907, Angoche: breve memoria sobre uma das capitanias-móres do Districto de Moçambique, Lisboa, Typographia do Annuario Commercial

Machel, S.M., 1985, 'Make Beira the starting-point for an organisational offensive', in B. Munslow (ed.), Samora Machel - An African Revolutionary: Selected Speeches and Writings, London: Zed Books: 73-80.

Machel, S.M., 1985, 'We are Declaring War on the Enemy Within', in B. Munslow, (ed.), Samora Machel: An African Revolutionary. Selected Speeches and Writings, London: Zed Books: 86-103.

Manor, J., 1999, The Political Economy of Democratic Decentralisation, Washington, DC: World Bank.

Massano de Amorim, P., 1911, Relatório sobre a ocupação de Angoche: Operações de campanha e mais serviço realizados, Anno 1910, Lourenço Marques: Imprensa Nacional.

Mbwiliza, J.F., 1991, A History of Commodity Production in Makuani, 16001900: Mercantilist Accumulation to Imperialist Domination, Dar es Salaam: University of Dar es Salaam Press.

Mello Machado, A.J., 1970, Entre os Macuas de Angoche, Historiando Moçambique, Lisboa, Prelo. 
Meneses, M.P., 2007, 'Pluralism, Law and Citizenship in Mozambique: Mapping the Complexity’, Oficina do CES, 291.

Meneses, M.P., 2008, 'Mulheres insubmissas? Mudanças e conflitos no norte de Moçambique’, Ex Aequo, 17: 71-89.

Meneses, M.P., Fumo, J., Mbilana, G., Gomes, C., 2003, ‘Autoridades Tradicionais no contexto do Pluralismo Jurídico’, in B.S. Santos and J.C. Trindade (eds.). Conflito e Transformação Social: uma Paisagem das Justiças em Moçambique, Porto, Afrontamento, volume 2: 341-425.

Newitt, M.D.D., 1972a, 'The Early History of the Sultanate of Angoche', Journal of African History 13 (3): 397-406.

Newitt, M.D.D., 1972b, 'Angoche, the Slave Trade and the Portuguese c. 18441910', The Journal of African History, 13 (4), 659-672.

Newitt, M.D.D., 1995, A History of Mozambique, London: Hurst \& Co.

OECD, 2005, Paris Declaration on Aid Effectiveness, Paris: OECD

O’Laughlin, B., 2000, 'Class and the Customary: The Ambiguous Legacy of the Indigenato in Mozambique’, African Affairs, 99 (395): 5-42.

Pélissier, R., 2000, História de Moçambique: formação e oposição, 1854-1928. Lisboa: Editora Estampa, 2 vol.

Pinto de Carvalho, A., 1988, 'Notas para a história das confrarias Islâmicas na Ilha de Moçambique’, Arquivo 4: 59-66.

Rita-Ferreira, A., 1967-1968, 'Os Africanos de Lourenço Marques’, Memórias do Instituto de Investigação Científica de Moçambique, 9 (C): 95-491.

Santos, B.S., 2006, 'The Heterogeneous State and Legal Pluralism in Mozambique', Law \& Society Review, 40 (1): 39-75.

Santos, B.S., Meneses, M. P., 2006, Identidades, Colonizadores e Colonizadores: Portugal e Moçambique, Relatório final do Projecto POCTI/41280/SOC/2001. Coimbra: CES.

Santos, B.S., Trindade, J.C., Meneses, M.P. (eds.), 2006, Law and Justice in a Multicultural Society: The Case of Mozambique, Dakar: CODESRIA.

Vansina, J., 1990, Paths in the Rainforests: Toward a History of Political Tradition in Equatorial Africa, Madison: University of Wisconsin Press.

Vines, A., 1991, RENAMO: From Terrorism to Democracy in Mozambique? London: James Currey.

Weimer, B., 1996, 'Challenges to Democratisation and Regional Development in Southern Africa: Focus in Mozambique’, Regional Development Dialogue 17 (2): 32-59.

West, H., Kloeck-Jenson, S., 1998, 'Betwixt and Between: ‘Traditional Authority’ and Democratic Decentralisation in Post-war Mozambique’, African Affairs 98: 455-484.

World Bank 2005, Mozambique Country Economic Memorandum. Sustaining Growth and Reducing Poverty, Washington, D.C., World Bank. 
